\title{
LA MODERACIÓN DE LAS PASIONES O INDICIOS DE ESTOICISMO EN LAS TROYANAS DE SÉNECA
}

\author{
Francisco Miguel Ortiz Delgado \\ Doctorando de la Universidad Autónoma Metropolitana-Iztapalapa \\ fmiguelod@gmail.com
}

\begin{abstract}
RESUMEN / ABSTRACT
En el drama Las troyanas de Séneca el Joven, según proponemos, existen argumentos e ideas de la filosofía estoica en torno a las emociones y las pasiones. Tales ideas, derivadas de la teoría ética-epistemológica estoica, están insertas en los discursos de personajes como Hécuba, Andrómaca, Agamenón o Helena. Séneca exhibe la historia-mito de la Guerra de Troya como una fuente de emociones erróneas, es decir, de pasiones que alejan a los personajes de la virtud-felicidad. Consecuentemente, el autor nos presenta discursos, en boca de sus personajes, que instan a evitar estoicamente esas pasiones, como lo son el miedo, el dolor o el orgullo excesivos.
\end{abstract}

Palabras clave: estoicismo, pasiones, emociones, Séneca, guerras, moral guerrera, Troya, moderación, virtud-felicidad.

\section{The Moderation of the Passions or Trails of Stoicism in Seneca's Troades}

We propose that in the dramatic play The Troades of Seneca the Young are arguments and ideas belonging to the stoic philosophy that analyze emotions and passions. Such ideas, derived from the ethical-epistemological stoic theory, are inserted on the speeches of characters like Hecuba, Andromache, Agamemnon or Helen. Seneca exhibits the history-myth of the Trojan War as a source of erroneous emotions, that is, of passions that remove happiness-virtue from the characters. Consequently the author presents us speeches, spoken by his characters, which urge to stoically avoid such passions like excessive fear, pain or pride.

KEYWORDS: stoicism, passions, emotions, Seneca, wars, warrior moral, Troy, moderation, virtue-happiness.

$\overline{R A}$

Las troyanas de Séneca es un drama que podemos describir como una secuela al relato de la Guerra de Troya, una continuación de la historia contenida en la Ilíada, que se ambienta inmediatamente después de la conquista de Ilión. En tal drama encontramos las palabras y los actos de las mujeres en la derrotada Ilión, de féminas como Andrómaca, Hécuba y Helena. Muchas de las palabras y los actos de los protagonistas, proponemos, son características del estoicismo.

La intencionalidad de los dramas senecanos es múltiple. Aparte del objetivo de poner el drama hecho en Roma por hablantes de latín, en alto, es evidente que tuvieron 
un propósito edificante y moralizante que se logró con recursos retóricos y estéticos. Dejando a un lado el aspecto literario y argumental, puntualizamos que Séneca emplea los hechos históricos y mitológicos, la Guerra de Troya, con un objetivo parenético, porque el filósofo latino desea ilustrar al público romano sobre el cómo controlarse ante las pérdidas personales provocadas por la guerra.

La cuestión bélica era un asunto tan perentorio al Imperio Romano pues, como comenta Sandbach (1975, p. 127), el estoicismo es una filosofía bastante apropiada para los guerreros, para los líderes que integraban la sociedad romana o la troyana, al enaltecer virtudes apropiadas para tal tipo de sociedades: valentía, justicia y moderación. Y Séneca parece querer mostrar en Las troyanas cómo debe comportarse el ser humano, en especial cómo deben comportarse, ante situaciones extremas, los reyes y los guerreros, y sus esposas, madres y hermanas.

De acuerdo con los estoicos, la derrota no es una desgracia, es un indiferente (adiáphora) para la consecución de la felicidad, pues no nos lleva en verdad a la infelicidad, lo único que sí nos llevaría a ésta es el actuar viciosamente, contra la naturaleza. Así, vemos que Séneca dio su versión, en Las troyanas, de un pasaje histórico-legendario en aras de un objetivo moral y político propio del estoicismo. Veamos entonces los indicios de los principios estoicos insertos en el drama de Séneca.

\section{Primer indicio: Hécuba y la muerte como un indiferente}

En Las troyanas, una de las recomendaciones del personaje Hécuba, dada a las mujeres troyanas en apuros y rodeadas de muerte, es característica del estoicismo: aceptar el sufrimiento enviado por los dioses, resignarse y, por último, considerar a la muerte como algo no dañino, incluso glorioso. Hécuba trata de convencer de aceptar la muerte de líderes y familiares queridos por sus interlocutores, es contraria a dejarse superar por las lágrimas y el dolor debido a su situación.

Estamos ante una alabanza a la muerte en el discurso de Hécuba:

Hacia otro dirigid las lágrimas vuestras: no es miseranda la muerte de mi Príamo; troyanas... "feliz Príamo", decid todas: libre va hacia sus manes profundos y nunca llevará en su vencida cerviz el yugo griego; él no ve a los atridas ni percibe al falaz Ulises; ni como presa del argólico triunfo, sometido llevará su cuello con los trofeos; sus manos acostumbradas a los cetros no las ofrecerá tras su espalda; ni, siguiendo carros de Agamenón, cuando él lleva consigo áureas cadenas en su diestra, será cortejo en la rica Micenas (Séneca, Las troyanas 142-155) ${ }^{1}$.

Toda traducción de Las troyanas de Séneca que aquí se cita es de la versión de Germán Viveros (en Tragedias, México, Universidad Nacional Autónoma de México). 
La consideración de la muerte como algo plenamente indiferente (adiáphora) para obtener la virtud-felicidad ${ }^{2}$ es una característica notable del estoicismo. "El término $<$ indiferencia> se dice en dos sentidos; en el primero significa lo que no contribuye ni a la felicidad ni a la desventura [...] En otro sentido [...] se aplica a lo que no pone en movimiento ni inclinación ni aversión" (Laercio VII 104)3. Son indiferentes "no preferibles [...], en las [cosas] del cuerpo, la muerte ${ }^{4}$, la enfermedad, la debilidad, el mal estado físico, la mutilación, la fealdad y cosas del mismo género" (Laercio, VII 106) Como la muerte es un indiferente para ser feliz, los estoicos incluso recomendaban, en ciertas ocasiones, elegir la muerte sobre la vida: como cuando uno está condenado a tener una vida viciosa, indigna y carente de honor. La vida viciosa no es aceptable para el estoico. "Nuestro Zenón [de Citio] utiliza este argumento: "Ningún mal es glorioso. Pero la muerte es gloriosa. Por consiguiente, la muerte no es un mal" (Séneca, Epistolas 82, 7/ S.V.F. ${ }^{6}$ I 196) ${ }^{7}$.

En el estoicismo se buscaba lograr una existencia decorosa y apegada a la virtud, entendida la virtud como el actuar siempre conforme a la Naturaleza o, lo que es lo mismo, conforme a los designios de Dios - que es la misma Naturaleza-, y para ello se necesita de la eliminación de las pasiones perniciosas. "[...] muchos estoicos [...] suponen que las pasiones del alma no son juicios del alma" (Galeno, Sobre las opiniones de Hipócrates y Platón IV 3, V 337 K, 348 Mueller/ S.V.F. I 209) ${ }^{8}$.

Por eso es que, ante una situación o suceso histórico, como la derrota total de una nación (como el caso de Troya), para los estoicos lo que los habitantes de la nación en ruinas deben perseguir es la resignación, la moderación de los sentimientos o la muerte voluntaria. Y a aquel que se quejase y temiese de la próxima muerte de uno mismo o de sus allegados, los estoicos como Epicteto replican irónicamente “¿Serán inmortales los demás hombres?" (Disertaciones II, VII 27).

Entonces, Hécuba sigue la idea estoica de que las personas nunca deben de perderse en las pasiones incorrectas como la desesperación, el odio, el miedo, la angustia, ni siquiera cuando se estuviera ante tal extrema situación. En su caso, manda que las troyanas no tengan ni desesperación, ni miedo, ni angustia, por la reciente muerte de su rey o por la de sus seres queridos (esto último lo sugerirá más tarde en el drama).

"Si con los griegos te agrada conversar, trata con Sócrates y con Zenón [de Citio]: el uno te enseñará a morir cuando sea necesario; el otro, antes de que lo sea" (Séneca,

2 La virtud, grosso modo, es para los estoicos lo único moralmente correcto, el bien supremo y el único bien donde residía la felicidad o eudaimonía. Diógenes Laercio VII 89.

Traducción López Eire, pp. 176-177.

Cursivas mías.

Trad. López Eire, p. 178.

Stoicorum Veterum Fragmenta.

Traducción de Capelleti en Los estoicos antiguos, p. 124.

Trad. Capelleti, p. 130. 
Epístolas 104, 21/ S.V.F. I 258) $)^{9}$ Y en esto parece Hécuba acercarse al estoicismo: ni padece por la muerte de Príamo ni teme su propia muerte, como se verá más adelante: "Dura e infeliz alma, vamos, escápate" (Las troyanas 958-968), se dice a sí misma.

Señalaba Cicerón que es aceptado por todos que es propio de los varones fuertes soportar el dolor, pero esta virtud (muy romana por cierto), según la tragedia de Séneca, también la poseían las mujeres. Séneca no teme entonces otorgar virtudes a las mujeres pese a que:

[...] virtud tomó su nombre [en latín] de vir. Mas es propia del varón especialmente la fortaleza, cuyos dos máximos deberes son el desdén de la muerte y el del dolor. Por consiguiente, éstos deben practicarse si queremos ser poseedores de la virtud, o más bien, varones, puesto que a los varones la virtud pidió prestado su nombre (Disputas tusculanas, II 43) ${ }^{10}$.

En otras palabras, Séneca da una característica del hombre a una mujer, a Hécuba, porque ésta desprecia la muerte, la infravalora como lo haría un buen estoico. Y al despreciar la muerte, o alabarla, como a la de Príamo, Hécuba da muestras de poseer la virtud llamada "fortaleza". Este personaje cumplió el deber estoico de desdeñar la muerte de su rey y sus seres queridos y, con ello, desdeñar el dolor que tales muertes podrían implicar. Según Cicerón existe otra razón, proveniente por igual del estoicismo, para alabar la muerte de Príamo: "La muerte es terrible para aquellos con cuya vida todo se extingue, no para aquellos cuya gloria no puede morir" (Cicerón, Las paradojas de los estoicos II, 18) ${ }^{11}$.

Luego, para Príamo la muerte no fue terrible ya que él obtuvo gloria, y esto lo sabía Hécuba, el rey murió peleando y fue derrotado, no por sus malas decisiones y acciones sino porque así estaba predispuesto por el Destino: hiciera lo que hiciera Troya caería, y tal soberano fue glorioso ("sometido llevará su cuello con los trofeos", afirma Hécuba) porque ni temió su muerte ni la de su descendencia al defender a su patria. La gloria sobrevive a uno mismo, pero, según los estoicos, no hay que dejarnos dominar por el placer de tal gloria, como veremos a continuación.

Segundo indicio: Agamenón y la eliminación de las pasiones del conquistador

Agamenón, de quien el troyano Paris había robado a Helena, orgulloso y satisfecho por la victoria de los suyos ante Troya, aconseja en la obra de Séneca:

Primeramente conviene conocer esto: qué debe hacer el vencedor; el vencido: soportar [victus pati]. Mandatos violentos, nadie los ha retenido largo tiempo,

Trad. Capelleti, p. 149.

Trad. Pimentel, p. 76.

Trad. Pimentel, p. 9. 
los moderados duran: y cuanto más alto Fortuna encumbró y levantó las riquezas humanas, por esto conviene que el dichoso se contenga más [supprimere felicem decet] y que tiemble ante variados azares [variosque casus], temeroso de los dioses demasiado favorecedores. Que lo grande en un momento es sepultado, vendiendo lo aprendí. [...] Lo reconozco, alguna vez tiránico y soberbio por mi poder, yo mismo me llevé más alto, pero abatió aquellas arrogancias esta causa, que hubiera podido dársela a otros: el favor de la Fortuna (Las troyanas 288-299).

Este discurso del rey Agamenón trata de convencer que la resignación del vencido, victus pati, ante los aparentes sufrimientos que la historia presenta, es una de las mejores cualidades que pudiera haber en el humano (resignación análoga a la que sugirió Hécuba a sus coterráneas), además de que argumenta que la moderación del vencedor no es menos virtuosa y elogiable, porque es en la victoria o la gloria y en el trato con los derrotados donde es apreciada la cualidad moral de los triunfadores. Pero Diógenes Laercio claramente nos dice que los estoicos consideraban la gloria como una cuestión indiferente para ser feliz: "las cosas indiferentes [...] no conducen a la felicidad ni a la infelicidad, v. gr., las riquezas, la salud, las fuerzas, la gloria, y semejantes" (Laercio VII, 72) ${ }^{12}$. Considerar la gloria como un bien puede llevar a la pasión, a lo incorrecto (según vamos explicando más abajo). Es sabido que los vencedores o dominantes difícilmente pueden evitar los excesos en la victoria puesto que, como todo pueden pedir de los vencidos, todo pueden obtener.

Los victoriosos y conquistadores que se privan de las tropelías y los excesos claramente pueden ser calificados como virtuosos, lo cual es un ejemplo exacto de moderación de las pasiones. Éstas, según la Stoa, son sentimientos excesivos que provienen de razonamientos perversos y equivocados que obtienen "su vehemencia y su fuerza de una elección vil y equivocada" (Plutarco, Sobre la virtud moral 3, 441 c/ S.V.F I 202) ${ }^{13}$. El estoicismo no afirma que las personas no deben sentir, por ejemplo, no establece que nunca debemos mostrar dolor; esto nos convertiría en unos insensibles, lo que afirma es que no debemos poseer sentimientos excesivos, desbordados, incontrolables y/o esclavizantes. Estos sentimientos excesivos constituyen las llamadas pasiones.

Los estoicos piensan que el verdadero sabio no padece las pasiones (de prepotencia o soberbia) del vencedor y el exitoso, pues nunca realiza razonamientos equivocados. Veamos las pasiones perniciosas clasificadas como "placeres" por los estoicos, que podemos identificar con las que Agamenón no desea que sus victoriosos compañeros en armas padezcan: "[1] rejoicing at another's misfortunes, [2] self-gratification, [3] trickery, and the like" (Estobeo II 90, 19-91, 9/ S.V.F. III 394) 14. "[1] regocijarse en los infortunios de otros, [2] auto-gratificación, [3] astucia, y similares"15. Todas estas

12 Trad. Ortiz y Sánz, p. 242.

13 Trad. Capelleti, p. 127.

14 Trad. de Long y Sedley en The Hellenistic Philosophers, p. 412.

15 Traducción propia. 
pasiones (1, 2 y 3), que seguramente algunos griegos vencedores de Troya estaban sintiendo, deben de ser expulsadas de la mente de uno para llegar a la felicidad.

El sabio estoico, sigue pues las recomendaciones que Agamenón da a sus compañeros vencedores:

[...] el sabio está libre de pasiones porque no está predispuesto a caer en esas enfermedades [...] El sabio no tiene orgullo, porque es indiferente tanto al renombre como a la insignificancia. [...] Y afirman [los estoicos] que todos los sabios son severos porque ni ellos personalmente tienen trato con el placer ni admiten de los demás lo que al placer se endereza (Laercio, VII 117-126) ${ }^{16}$.

Los soldados y líderes griegos, a sugerencia y libertad creativa de Séneca, tenían que acercase al ideal de sabio al eliminar el orgullo que pudiera provenir del renombre o la gloria del triunfo sobre Troya. Consideramos que el estoicismo establece una causa epistemológica para toda acción histórica porque cada acontecimiento se debe a la decisión de uno o varios individuos. Es decir, para que alguien pueda decidir algo, debe hacer uso de su libertad de elección, primero recibirá a través de sus sentidos una representación o impresión, luego realizará un proceso epistémico: el dar o no

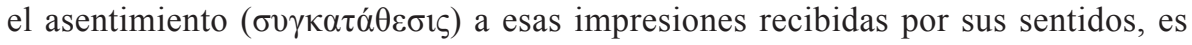
decir, aceptarlas o rechazarlas como verdaderas. Lo anterior lo mencionamos porque el individuo sabio estoico, para que permanezca sabio, debe analizar sin falta y con detenimiento las impresiones que percibe: "we know it is distinctive of the philosopher always to examine his impressions critically" (Salles 2007, 294). Entonces, los aqueos triunfadores, aun en su victoria, debían siempre analizar las impresiones que percibían. Si recibieron la impresión de gloria como un bien, debían de rechazar tal impresión como falsa (aceptarla los lleva, en efecto, a la pasión, a lo único incorrecto que existe, que es el vicio) porque el único bien es, repetimos, la virtud.

Pero el individuo no sabio, como los griegos triunfadores sobre Troya, no distinguirá las impresiones o representaciones falsas de las verdaderas, como dijo Epicteto, "muchas veces te sacan de quicio las representaciones [impresiones] y te alteras y te vence su encanto; y a veces supones que tales cosas son bienes y, luego, que esas mismas cosas son males" (Disertaciones II, XXII 6); quien no es filósofo sabio, según los estoicos, jamás distinguirá lo que es realmente "benigno" ni lo que es "maligno"; luego, los no sabios caen en la pasión por errores epistemológico-psicológicos (Brennan 2005, 82112): los no-sabios nos dejamos ofuscar por ciertas impresiones al no saber cuál es el verdadero bien supremo. Séneca otorga rasgos de "rey-sabio" (estoico) a Agamenón, pues a éste ni lo sacaron de quicio las representaciones de la gloria y la victoria como bienes, ni se alteró por el encanto del renombre, ni se apasionó por el placer del éxito de su campaña; en general mantuvo una actitud moderada, estoica. 
Para los estoicos, el proceso epistemológico de responder a las impresiones percibidas, si siempre se hace correctamente, lleva a la virtud y, con/por ello a la felicidad (la felicidad última implica a la virtud). "La felicidad, según los discípulos de Zenón, de Cleantes y de Crisipo expresaron, es el buen decurso de la vida" (Sexto Empírico, Contra los matemáticos XI 30/ S.V.F. I 184) ${ }^{17}$. Y "la virtud [es] bastante para la felicidad" (Laercio VII, 88) ${ }^{18}$, es decir, es suficiente con ella sola para conseguir la felicidad. La virtud es el bien supremo al cual la racionalidad humana debe ir. El Agamenón virtuoso de Las troyanas parece estar satisfecho con el triunfo, mas no apasionado con el mismo.

Agamenón, en su discurso citado, propone no dar el asentimiento estoico (otorgado a las impresiones percibidas por los sentidos) a la supuesta felicidad que les da la gloria. Arguye a sus compañeros que aquellos que han subido tan alto y obtenido elevada gloria se prevengan de caer y eliminen su aparente felicidad (supprimere felicem decet). Ordena, en términos estoicos, no asentir a la aparente felicidad devenida de haber ganado la guerra. El argumento "estoicizante" se refuerza con dos puntos: 1) la caída para los triunfadores será más dura (al descubrir que la felicidad que sentían gozar no era una impresión verdadera, no era en verdad felicidad), y 2) la vida es contingente y azarosa; el no-sabio desconoce cuáles son los designios de Dios y por esto no debería mostrar prepotencia.

Agamenón nos dice que tanto en el triunfo como en el fracaso el hombre debe moderarse, un alto objetivo estoico. Se debe estar atento ante las múltiples vicisitudes de la historia (estar alerta ante las falsas impresiones que se nos presentan en los diferentes acontecimientos), para comportarse de la mejor manera ante todas las situaciones, con lo que se llegará a la felicidad verdadera.

\section{Tercer indicio: Andrómaca, Hécuba y la imperturbabilidad}

Otra protagonista del drama Las troyanas fue Andrómaca, quien asegura a sus coterráneas que el dolor que están padeciendo es poco ante la pérdida que ella sufrió previamente a la caída de los muros de su ciudad: habla de la humillante muerte de su esposo Héctor por obra de la espada del aqueo Aquiles. Ante este hecho Andrómaca cuenta cómo soporta su tristeza:

[...] abrumada y abatida, todo lo que acaeció embotada e impasible por las desgracias, sin sensación lo sobrellevo (Las troyanas 416-417).

Lo dicho por el personaje perfectamente puede pasar por la descripción de la ataraxía que los estoicos perseguían: las aparentes desgracias deben llevarse con imperturbabilidad.

17 Trad. Capelleti, p. 119.

18 Trad. Ortiz y Sánz, p. 248. 
Aristón de Quíos... dijo que el fin es vivir en estado de imperturbabilidad [ataraxía] con respecto a las cosas intermedios entre la virtud y el vicio, sin renunciar a dicho estado al admitir grados entre los dos y considerándolas equidistantes [a todas]. El sabio se parece al buen actor [a propósito de las tragedias], que ya interpreta el papel de Tersites, ya el de Agamenón, y a ambos los representa adecuadamente (Laercio VII, 160) ${ }^{19}$.

Vemos que ante un dolor tal como la muerte de todos los familiares y la conquista de la nación propia, lo que los personajes de Las troyanas argumentaban y demostraban era aguante, fortaleza y la creación de una manera de tolerar tales acontecimientos para no caer en la desesperación:

Nada es malo, dice [Zenón], sino lo que es torpe y vicioso... Nunca algo, dice, molesta, aunque duela, si conduce a la vida feliz, la cual consiste solamente en la virtud. [El dolor], sin embargo, se ha de rechazar [convenciéndonos de que es un indiferente]. ¿Por qué? Es áspero, contrario a la naturaleza, difícil de tolerar, triste y duro (Cicerón, Disputaciones tusculanas II 29/ S.V.F. I 185) ${ }^{20}$.

La ataraxía o imperturbabilidad era la característica del sabio, según los estoicos. Para el primer estoico, Zenón de Citio, las personas deben lograr "una disposición de ánimo serena e impertérrita con respecto a las demás cosas que no son bellas ni vergonzosas [como la muerte] [...] y se abstengan de las contrarias [a la virtud], por razón y no por miedo, sin temerlas en absoluto" (Ateneo VI, 233 b-c/ S.V.F. I 239) ${ }^{21}$. Para el estoico Epicteto quien es libre "no admite turbaciones o impedimentos de ningún otro más que de sí mismo" (Disertaciones I, XIX 7). Andrómaca, en términos estoicos, es libre en su interior y por naturaleza, aunque caiga en una esclavitud física ante los aqueos. Lo que es lo mismo, ella permanecerá libre porque conserva una actitud (virtuosa) de imperturbabilidad (no es esclava de sus pasiones), incluso ante su próxima caída en la esclavitud exterior. La distinción entre libertad/esclavitud interior y libertad/esclavitud exterior es un tema clásico en el estoicismo medio y tardío que, según observamos, es explotado magistralmente por Séneca.

Hécuba, también en una actitud representativa de los estoicos, trata de convencer a Andrómaca de que debe resignarse ante su próxima esclavitud (física) y que hasta debería estar "feliz" porque uno de los enemigos griegos desea estar con ella, en matrimonio, aunque esto fuera consecuencia de la fuerza, y asevera que, entre todas las troyanas, debería ser la más contenta con su Fortuna:

Hace poco una turba feliz ceñía mis costados; como madre, me fatigaba de repartir besos entre tantos y entre tanta grey; ahora ella sola está, además de mi deseo; compañera, consuelo de la afligida, descanso ésta, la cría toda de Hécuba, por

Trad. Capelleti. 
esta sola voz [por Andrómaca] soy llamada madre. Dura e infeliz alma, vamos, escápate: finalmente, este solo funeral perdóname. Riega el llanto las mejillas y lluvia súbita cae del vencido rostro. ¡Alégrate, goza, hija! ¡Cuánto querría Casandra tus tálamos! (Las troyanas 958-968).

El párrafo anterior está plagado de un patetismo que, pese a tener su dosis realista, también podría darnos la sensación de estar ante personajes que sobredimensionan los hechos, esto para probablemente conseguir un efecto estético-retórico al igual que parenético. Hécuba conserva un optimismo ante tantas desgracias y lo conserva, extraordinariamente, pese a ver asesinados a todos sus hijos excepto a una, Andrómaca, y pese a haber vivido la muerte de su esposo y la destrucción de su nación. Su comportamiento también es cercano al del sabio estoico quien "se comporta sin apetito [ni excesiva aflicción] frente a todas las cosas externas y sólo con un impulso moderado. [...] [Toda emoción excesiva] rebaja, subordina el hombre a las cosas, y a aquellos hombres que disponen de las cosas y, por consiguiente, destruye la libertad" (Barth 1930, 154); es decir, no tiene "faulty judgements manifested in 'excessive' [...] impulses" (Long 2002, 245). Hécuba no deja de llorar ni de decir que tiene un infeliz alma, pero esto lo hace, consideramos, sin caer en excesos ni pasiones (ni impulsos excesivos), lo hace, de cierta manera, sabiamente; si no lo hubiera hecho de esta forma moderada ella hubiera caído en la desesperación y/o el agobio, y nunca hubiera sido capaz de recomendarle a su hija que se alegrara. Dentro del sufrimiento de Hécuba hay moderación, hay orden y cierta calma, cualidades que, según Séneca en una de sus cartas, tiene quien es feliz.

What is happy life? Peacefulness and constant tranquility. Loftiness of mind will bestow this, and consistency which holds fast to good judgement. How are these things reached? If all of truth has been seen, if orderliness, moderation, and seemliness are preserved in actions, and a will which is guiltless and kindly, focused upon reason and never departing from it, as lovable as it is admirable. (Séneca, Epistolas 92.3) ${ }^{22}$.

¿Qué es la vida feliz? Calma y constante tranquilidad. La mente elevada [grandiosa] otorgará esto y consistencia que la conserva firme [a la persona] para el correcto raciocinio. ¿Cómo se alcanzan estas cosas? Si la verdad completa es vista; si el orden, la moderación y el decoro son conservados en los actos, y una voluntad, que es pura y amable, enfocada en la razón y que nunca se alejará de ella, en tanto que es querida y admirable ${ }^{23}$.

Hécuba tiene pues una mente elevada que le permite ser coherente y moderada, le permitiría ser feliz incluso ante las mayores de las desgracias que le pudieran ocurrir a alguien.

22 Trad. Long y Sedley.

23 Traducción propia. 
Cuarto indicio: la aceptación de la esclavitud física, de la situación o del Destino propios

Lo que el Dios estoico designa no se puede cambiar y tal designación siempre tiene una buena razón, éticamente hablando, de ser. Por eso es que el humano debe seguir al Dios-Destino, el ser humano tiene pues un "principio de alineación" con el siempre benigno Destino (Salles 2014). La aceptación del Destino puede hacer que la vida sea más fácil (como la tendría el sabio estoico quien siempre acepta su Destino), esta aceptación podría encontrarse, probablemente cayendo en una sobreinterpretación que es de cualquier forma pertinente, en Andrómaca y en Hécuba, porque ambas troyanas tienen una actitud bastante valiente ante su situación de "desgracia". Una actitud que los estoicos recomendarían tener siempre.

En Las troyanas hallamos otra apreciable descripción de lo que es el aparente sufrimiento, o al menos de un factor que lo dispara: la comparación de la situación de dos personas, un recurso o estrategia de recurrente uso en la retórica de la Antigüedad (Pernot 2013, 167 y 178). No solo con las comparaciones entre uno mismo y los demás seres humanos se puede argumentar, en términos coloquiales, que se es feliz o infeliz, sino también con las comparaciones temporales. Comparar pues el presente con algún otro periodo de la historia personal, grupal, nacional o la historia de los otros, es una común estrategia de argumentación. Alguien puede ser dichoso en el presente con respecto a su pasado, o infeliz ahora por compararse con el ayer. Pero para algunos, como para Helena, desdicha hay tanto en el pasado como en el presente.

¿Duro y odioso y grave es sobrellevar la servidumbre? Soporto este yugo desde hace tiempo, por diez años cautiva. ¿Postrada está Ilión, derribados sus penates? Perder la patria es grave, más grave es temerle. A vosotros os alivia de mal tan grande uno acompañado; contra mí vencedor y vencido se enfurece [victor et victus furit] (Las troyanas, pp. 909-914).

Aquí Helena muestra un discurso oneroso: ante la posibilidad de ser llevada esclava por los aqueos, aquellos a los que por nacimiento e himeneo pertenecía, comenta que ya ha sido esclava de los troyanos durante todo el tiempo que duró la guerra, diez años. Estimaba que era un funesto Destino para ella (una no-sabia) tanto si triunfaban los aqueos como si ganaban los troyanos. No obstante, este es otro personaje que soporta sus desdichas (cuasi) estoicamente y ni comete suicidio, ni piensa en él, como si a los personajes de los dramas humanos senecanos les surgieran rasgos de la virtud estoica ante las "desgracias".

Helena tiene, para con los imponentes destructores de Troya, la actitud que Zenón de Citio adoptó cuando se iba a entrevistar con el rey Antígono: "no estaba angustiado [Zenón]" porque el soberano "no tenía poder sobre nada de lo que aquél [Zenón] admiraba, y las cosas sobre las que tenía poder no le importaban nada a aquél" (Epicteto, Disertaciones II, XIII 14).

Helena es una heroína estoica porque "soporta" el yugo, "sobrelleva" la servidumbre, sin sufrir en demasía. Ella no se deja derrotar por el sufrimiento que 
podría provocar el ser esclava de los aqueos triunfadores. Posee, más bien, la actitud del "hombre bueno" y libre quien ni "padece ni se agobia", ni gime, ni palidece, ni tiembla (Epicteto, Disertaciones II, XIII 17-18), ante los que puedan ejercer un poder (exterior) sobre él. Volvemos a observar la división entre libertad exterior, que es un indiferente, y libertad interior, que es un bien por ser la característica del individuo sabio-virtuoso.

Frente a la perspectiva de la caída y la desaparición de ciudades como la de Troya, de la conquista de civilizaciones enteras, los no-sabios podríamos argumentar que la historia humana es una serie de "desgracias" (sin sentido e injustificables) que llegan hasta el presente. Pero los estoicos dirían que esas desgracias son aparentes y que tienen un sentido, el cual es el que le ha dado (desde la eternidad) el Dios-Destino y argumentarían que lo que no tiene sentido porque está contra la Naturaleza-Dios son las emociones no virtuosas de las personas, las pasiones o emociones incorrectas ${ }^{24}$. Éstas surgen tanto en los que ganan como en los que pierden una guerra (victor et victus furit), surgen tanto en los que supuestamente deben de estar alegres como en los que no; pasiones como el enojo evitan que el humano llegue a la eudaimonía porque lo llevan a realizar actos viciosos.

[...] una providencia divina como la sostuvieron esforzadamente los estoicos, presupone una capacidad en Dios o en la Naturaleza para producir obras buenas. Los estoicos sostenían que éste es el mejor de todos los mundos posibles; no obstante aparentar imperfecciones aquí y allá, la Naturaleza organiza cada una de sus partes en modo tal que la armonía está presente en su conjunto (Long 1984, 164).

Lo que Séneca recomendaría para soportar nuestra impotencia ante los hechos de la historia se encuentra en los discursos de Hécuba y de Agamenón. Y esto es claro porque también nos lo recomienda directamente en una de sus epístolas, al citar al estoico Cleantes, quien epidícticamente instó a adorar y obedecer al Destino-Dios-Naturaleza (si no podemos cambiar nuestro Sino, es mejor obedecerlo):

Condúceme, oh padre, y señor del excelso polo,

A donde te plazca; no hay demora alguna en obedecerte.

Me hago presente sin pereza. Haz que no quiera: te seguiré llorando,

Y sufriré como malo lo que podía sufrir como bueno.

Los hados conducen al que quiere; [pero] arrastran al que no quiere (Epístolas $107,10)$.

Queremos, por último, aquí citar al emperador estoico (tardío) Marco Aurelio para demostrar la consistencia del pensamiento estoico en torno a la resignación con respecto a la situación y a los sucesos que a cada quien le "toca vivir". Las tragedias senecanas

24 Las emociones incorrectas en el estoicismo son cuatro, características del no-sabio o virtuoso: Deseo, placer, temor y desánimo (Brennan 2005). 
son consecuentes con este pensamiento. Marco Aurelio argumenta razones para aceptar el Destino, desgraciado o no, asignado a cada uno de nosotros:

[...] la naturaleza, cualquiera que sea, nada produce que no se adapte al ser gobernado por ella. Por consiguiente, conviene amar lo que te acontece por dos razones: Una, porque para ti se hizo, y a ti se te asignó y, en cierto modo, a ti estaba vinculado desde arriba, encadenado por causas muy antiguas; y en segundo lugar, porque lo que acontece a cada uno en particular es causa del progreso, de la perfección y ipor Zeus! de la misma continuidad de aquel que gobierna el conjunto del universo (Meditaciones V, 9).

Helena sufre lo malo y lo bueno que le acontece sin exceso de sufrimiento, sin ser arrastrada por el Destino. Ella se sabe pieza clave de los acontecimientos desencadenados, pero no parece tener, en Séneca, un sentido mayor de culpabilidad ante esos aciagos sucesos. A Helena le fue asignado el papel de Helena, en el drama de la Guerra de Troya; es decir, ella, como persona real, tenía como su destino el papel de ser secuestrada por Paris, el de provocar la ira de aqueos y troyanos por igual, para que con esto se cumpliera lo establecido por el Dios-Destino: la desaparición de Troya. En verdad, como se colige del discurso de Helena, hay destinos personales menos funestos que el de ella, pero esta mujer sobrellevó el suyo, en Las troyanas, con una moderación estoica de los sentimientos.

Quinto y último indicio: Helena et alia y las "desgracias" o el dolor como indiferentes (superables)

Ante tantas penas y tristezas que componen las tragedias senecanas, muchas veces se muestra un optimismo (¿estoico?), hasta en los más desdichados. En Las troyanas, un pasaje plantea que, ante las contrariedades más onerosas, debemos buscar, por decirlo coloquialmente, el lado bueno (en el estoicismo mucho-o, más bien, todo- es cuestión de perspectiva, de encontrar la perspectiva verdadera).

Helena le señala a Andrómaca que debe de tomar mejor actitud ante su suerte:

Generosa doncella de casa dardania, mejor dios ha comenzado a mirar a los afligidos y se prepara a dotarte de feliz tálamo. Connubio tal ni la propia Troya salvada, ni Príamo te lo daría. [...] [y luego agrega para ser más tajante] Depón los atuendos escuálidos, los festivos toma, olvida tu cautiverio; aplaca tu erizada cabellera y permite que esa crin sea peinada por experta mano. Esta desventura tal vez te pondrá de nuevo en más elevado solio (Las troyanas 884-887).

Helena toma la actitud que un estoico recomendaría ante las calamidades. No solo aprecia Helena la posibilidad de una vida y un futuro mejor, quizá no para ella-Helena solo se resigna pero, así, no sufre viciosamente-, empero sí para Andrómaca, y hasta maneja la idea de que las caídas personales pueden hacer que uno posteriormente se encumbra aún más. Sin por ello caer en una ambición desmedida, un sentimiento incorrecto. En efecto, la pena o dolor o aflicción, para el estoicismo, es la mera opinión de un mal 
presente reciente; en cuanto la (aparente) desgracia que alguien haya padecido quede atrás en el tiempo, se suavizará la opinión y el sentimiento hacia ella. Por eso, Helena, como muchos de nosotros, sabe que "el tiempo lo cura todo".

Juzgo [dice Cicerón] [...] que la aflicción [aegritudinem] es la opinión de un mal presente, en la cual opinión se halla aquello: que es oportuno experimentar aflicción [reiteramos, los estoicos no decían que uno nunca debía mostrar dolor pues esto nos convertiría en unos insensibles, sino que no había que dejarnos sentir un dolor excesivo].

Zenón [de Citio] añade rectamente a esta definición que aquella opinión de un mal presente es reciente. Mas de tal manera interpretan [los estoicos] esta palabra [aegritudo], que sostienen no sólo que es reciente aquello que ha acaecido un poco antes, sino que se llama reciente durante todo el tiempo que, en aquel mal opinado, se halle alguna fuerza, de modo que con ella se vigoriza y tiene cierto verdor (Cicerón, Disputas tusculanas III 74-75) ${ }^{25}$.

Cuando uno no puede imaginar peor situación que la conquista y la destrucción de la nación propia, la muerte o esclavización de los familiares, así como el ser constreñido a casarse con los conquistadores, con quien no se desea, por ser éstos los asesinos de los familiares y conocidos. Aún en este escenario descrito, Helena encontró razones para que Andrómaca se sintiera bien o, al menos, para que tuviera la esperanza de que quizá tendría un futuro mejor. El estoico Cleantes juzgó como el "deber único del consolante el mostrar que aquello [de lo que se duele, por lo que se sufre] no es en absoluto un mal" (Cicerón, Disputas tusculanas III, 76) ${ }^{26}$. Helena es el consolante de Andrómaca y le intenta mostrar que aquello por lo que sufre no es un mal, sino que incluso la puede haber llevado a un posible "bien" para ella. La consolante muestra a Andrómaca que la muerte de sus familiares y la destrucción de su ciudad no es un mal absoluto, pues aun en estas aparentes desgracias se encuentran razones para alegrarse.

Helena incita a la fortaleza, mencionando la posibilidad de un futuro mejor para los vencidos sobrevivientes de la Guerra de Troya; Agamenón incita al sosiego de los vencedores, mencionando la posibilidad de un futuro funesto para ellos. La primera logra cierta fortaleza al asegurar que un futuro puede traer fortuna más alta a los infelices de ahora, el segundo al aludir que el futuro puede hacer caer más fuerte a los dichosos de ahora por lo alto que se encuentran (la confianza en la veleidad del Destino). Ambos intentan combatir las pasiones de sus interlocutores. Helena trata de aplacar la pasión llamada dolor (desbordado), el rey trata de aplacar la pasión llamada soberbia (desbordada).

Con todos estos consejos moralizantes rescatados a lo largo de Las troyanas, con toda esta retórica terapéutica, aplicable a cualquier otra guerra y época, los vencidos deben obtener esperanza y tranquilidad y los vencedores mesura y tranquilidad. Así, la 
visión de un futuro nos permite sobreponernos ante las aparentes desgracias del pasado o de nuestra propia historia. Y ese sosiego lo transmiten los personajes de Séneca a través de las virtudes propias definidas por el estoicismo: porque Andrómaca, Hécuba y Helena (las troyanas), y Agamenón el aqueo, poseen claramente virtudes estoicas. Poseen con claridad: la "magnanimidad", definida por los estoicos, según Diógenes Laercio, como "el conocimiento $<0>$ el estado de ánimo que nos coloca por encima de los sucesos cotidianos, tanto buenos como malos"; poseen la "paciencia", que es "el conocimiento o el hábito que aconseja lo que hay que aguantar, lo que no y lo que tanto puede soportarse como no"; y poseen la "perspicacia" que es "el hábito pronto a descubrir al instante lo que debe de hacerse" (Laercio VII, 93) ${ }^{27}$.

Aun cuando nos encontremos en la época y en el momento en que nuestra nación caiga, en que nuestra patria desaparezca, aún ahí podemos y debemos encontrar aliento y esperanza a través de las palabras de la filosofía estoica. El estoicismo no busca desaparecer el dolor (a fin de cuentas, éste es parte de la vida misma como lo son muchas cosas más, como la muerte, la guerra, etc.) sino moderarlo, cambiando la perspectiva sobre él mismo. Los estoicos sugieren desaparecer las pasiones, como el miedo excesivo, confrontándolas o negándolas racionalmente, para así nunca dejarse llevar por ellas.

\section{Comentario final: La filosofía o retórica de la historia de Séneca}

Séneca, a través de sus tragedias, nos muestra el sufrimiento de los no-sabios, quienes, según el estoicismo, no comprenden o no saben que existe un principio normativo y moral único. Y, sin embargo, los personajes senecanos repentinamente comienzan a actuar o a proferir discursos acordes con las recomendaciones estoicas de controlar siempre los sentimientos y los actos de uno mismo. En muchos sentidos, los protagonistas de Las troyanas comienzan a actuar de acuerdo con los designios del Dios-Naturaleza estoico, es decir, actúan virtuosamente. Ser virtuoso, según estableció Zenón de Citio, consiste en "vivir de modo acorde con la naturaleza". (Lactancio, Instituciones divinas III 8$)^{28}$. Y vivir acorde a la naturaleza es tanto vivir de acuerdo a la Naturaleza-Dios como vivir de acuerdo a la naturaleza de uno mismo, es decir, la humana (Vogt 2008); y la naturaleza humana consiste en actuar siempre racionalmente, esto es, controlando las pasiones, que son debidas a decisiones "irracionales".

Realizar ciertos actos como el que realizaban algunos protagonistas de las tragedias grecorromanas: asesinato de los propios hijos, el asesinato de la propia madre o el asesinato de un hermano, simplemente no es apropiado para el ser humano, no corresponde a la naturaleza humana ni a la divina.

Trad. Capelleti. 
Cada suceso, tanto histórico como cosmológico, tiene un porqué ético-ontológico debido también a que Dios se encuentra no solo en cada suceso sino también en cada cosa, sensible o no sensible. En otras palabras, el estoicismo sustentaba un particular panteísmo (Bénatouil 2009, 24-25) ${ }^{29}$ y, repetimos, como Dios es bueno por su Naturaleza, luego, todo cuanto sucede y existe en el universo, incluyendo los hechos divinos, los cosmológicos y los históricos, es bueno y tiene un porqué o para qué. La explicación estoica de los acontecimientos, como los de la Guerra de Troya, se encuentra tanto en la constitución física del cosmos como en la argumentación ético-ontológica.

En los estoicos y en Séneca en particular, no hay distancia entre el mito y la historia. Ambos se explican con los mismos términos metafísicos (por Dios) y cosmológicos (por la materia), así como con una retórica didáctica y moralizadora. En los dramas de Séneca, el conocimiento y el ejercicio de la escritura no "permitió ser perceptible la distancia entre muthos e historia y, análogamente, entre pasado y presente" (Hartog 2011, 49). La búsqueda de la verdad dentro de los hechos históricos no era la principal preocupación ni ocupación de los estoicos, sino la utilización de esos hechos para aleccionar al estudiante de filosofía, al que quiere ser virtuoso. Fuera cual fuera la versión de un mito o de un acontecimiento histórico, los dos eran explicados a través de la búsqueda de la verdad filosófica, dejando a un lado la "verdad" mitológica o histórica.

El lenguaje del teatro y de las historias que representa Séneca puede ser adecuado para su propósito de ejemplificar el comportamiento humano no-correcto a los romanos. Las tragedias de Séneca pueden tener un deliberado fin pedagógico: inspirar y convencer de actuar con corrección moral. Un fin pedagógico y moral (deliberado o no) seguramente lo tienen las tragedias senecanas, como lo poseen muchos libros de historia que, aún con intencionalidad objetiva, apolítica y no juzgadora de la moral, se publican hoy en día. Concordamos con Luis González y González en que "se siguen haciendo libros [sobre historia, como se escriben libros artísticos] con intención placentera, edificadora y revolucionaria. Por otro lado, aun sin proponérselo, todo libro de historia produce placer, edificación o rebeldía, [...] No es una panacea, pero sí un instrumento adecuado para resolver problemas sociales" (2009, 314-315).

En esto último, Séneca y los estoicos estarían de acuerdo; el estudio o alusión a la historia es un medio de la retórica filosófica para intentar resolver los problemas de la humanidad. La filosofía, bien orientada, según la mayoría de los filósofos griegos antiguos, es la solución o panacea a los sufrimientos de las sociedades, pero no porque elimine lo que causa los sufrimientos (hambre, pobreza, muerte, etc.), sino porque puede cambiar la actitud humana ante esas causas, en el caso de la Stoa, al hacer que se (re) consideren no como causas sino como indiferentes para la obtención de la felicidad, y puede y debe hacer uso de cualquier herramienta para lograr su cometido. En el estoicismo el hombre y la mujer pueden ser felices incluso con hambre, enfermedad,

29 Para una revisión amplia e interesante de la teología estoica, véase el capítulo 9 "Stoic philosophical theology" de Kempe Algra, en God and Cosmos in Stoicism, Ricardo Salles (ed.). Nueva York: Oxford University Press. 
pobreza, esclavitud, etc., porque lo que hace infelices a los humanos no son estas cosas sino la idea negativa que se tiene hacia estas cosas.

Uno de los más fértiles estoicos, Crisipo, argumentó con más énfasis que es precisamente en la razón donde habitan las emociones, y que será mediante el correcto uso de las habilidades racionales y su capacidad de "selección, evaluación y visión" (Nussbaum 2002, 471) que podremos moderar y controlar las susodichas emociones, evitando que se conviertan en emociones incorrectas, es decir, en pasiones. Y el teatro era un buen recurso para enseñar todo lo anterior. Así, las "pasiones" y "sufrimientos" de la historia, como las causadas por la caída de Troya, son sucesos utilísimos y bien empleados por Séneca en su afán que, sugerimos, es simultáneamente retórico, aleccionador, moralizante $\mathrm{y}$, probablemente, difusor de las ideas estoicas.

\section{Referencias bibliográficas}

Algra, Kempe (2009), "Stoic philosophical theology", en Ricardo Salles, ed., God and Cosmos in Stoicism. Nueva York: Oxford University Press; pp. 224-252.

Barth, P. (1930), Los estoicos. Luis Recasens, traductor. Madrid: Revista de Occidente. Bénatouil, Thomas (2009), "How industrious Zeus can be?", en Ricardo Salles, ed., God and Cosmos in Stoicism. Nueva York: Oxford University Press; pp. 23-45.

Brennan, Tad (2005), The Stoic life. Emotions, duties and fate. Nueva York: Oxford University Press.

Capelleti, Ángel, traductor (1996), Los estoicos antiguos. Madrid: Editorial Gredos.

Cicerón, Marco Tulio (1979), Disputas tusculanas. Tomos I y II, Julio Pimentel, traductor. México: Universidad Nacional Autónoma de México.

(2000), Las paradojas de los estoicos. Julio Pimentel, traductor. México: Universidad Nacional Autónoma de México.

Epicteto (2010), Disertaciones por Arriano. Paloma Ortiz García, traductora. Madrid: Biblioteca Clásica Gredos.

González y González, Luis (2009), El oficio de historiar. Zamora: El Colegio de Michoacán.

Hartog, Francois (2011), Evidencia de la historia. Norma Durán, traductora. México: Universidad Iberoamericana.

Laercio, Diógenes (1972), Lives of eminent philosophers. R.D. Hicks, traductor. Cambridge: Harvard University Press. Recuperado de http://www.perseus. tufts.edu/hopper/text?doc=Perseus\%3Atext\%3A1999.01.0257\%3Abook\%3D 7\%3Achapter\%3D1.

(1990), Los filósofos estoicos. Antonio López Eire, traductor. Barcelona: Promociones y Publicaciones Universitarias.

(2003), Vidas de los filósofos más ilustres. José Ortiz y Sanz, traductor. México: Editorial Porrúa. 
Long, Anthony (2002), Epictetus, A stoic and socratic guide to life. Nueva York: Oxford University Press.

(1996), Stoic studies. Nueva York: Cambridge University Press.

Long, Anthony y D. N. Sedley, traductores y editores (1987). The Hellenistic Philosophers. Cambridge: Cambridge University Press.

(1984), La filosofía helenística. Estoicos, epicúreos, escépticos. P. Jordán de Urría, traductor. Madrid: Alianza Editorial.

Marco Aurelio (1977), Meditaciones. Ramón Bach Pellicer, traductor. Madrid: Editorial Gredos.

Nussbaum, Martha (2002), La terapia del deseo: Teoría y práctica en el ética helenística. Barcelona: Paidós.

Pernot, Laurent (2013), La retórica en Grecia y Roma. México: Universidad Nacional Autónoma de México.

Salles, Ricardo (2014), "Epictetus and the causal conception of moral responsibility and what is eph'hemin", en P. Destrée, R. Salles y Marco Zingano, eds., What is Up to Us? Studies on Causality and Responsability in Ancient Philosophy. Sankt Augustin: Academia Verlag; pp. 169-182.

(2007), "Epictetus on moral responsibility for precipitate action", en P. Destrée y C. Bobonich, eds., Akrasia in Greek Philosophy. Brill: Philosophia Antiqua; pp. 289-302. Disponible en: https://www.academia.edu/11190457/ Epictetus_on_moral_responsibility_for_precipitate_action, consultado en agosto 2016.

(2009), Los estoicos y el problema de la libertad. México: Universidad Nacional Autónoma de México.

Sandbach, F. H. (1975), The stoics. Londres: Chatto \& Wind Ltd.

Séneca, Lucio Anneo (1998). Las troyanas, en Tragedias. Germán Viveros, traductor. México: Universidad Nacional Autónoma de México.

Vogt, K. M. (2008), Law, reason and the cosmic city. Nueva York: Oxford University Press. 